
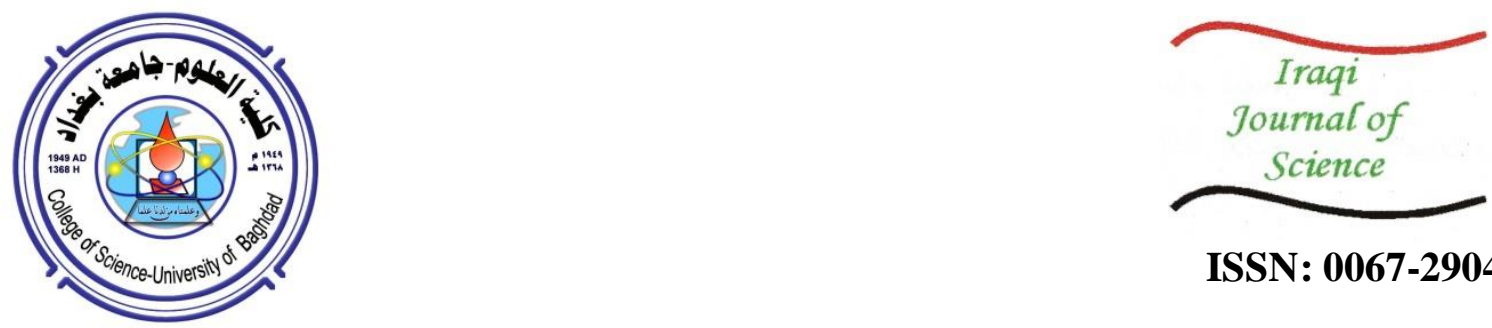

ISSN: 0067-2904

\title{
UV-Exposure effect on the mechanical properties of PEO/PVA blends
}

\author{
Nahida. J. Hameed
}

University of technology/Applied science school

Received: 6/7/2020

Accepted: 29/9/2020

\begin{abstract}
Poly ethylene oxide PEO / Poly vinyl alcohol PVA blends were prepared by cast method at different ratios of (25\% PEO/75\% PVA, 30\% PEO/70\%PVA, $35 \% \mathrm{PEO} / 65 \% \mathrm{PVA}, \quad 40 \% \mathrm{PEO} / 60 \% \mathrm{PVA}$, and 50\% PEO/505PVA). Samples miscibility , and thermal stability were studied by using differential scanning calorimetry(DSC), and thermo gravimetric analysis (TGA) analysis. The results proved that there was one glass transition temperature $\left(\mathrm{Tg}=160^{\circ} \mathrm{C}\right)$ at $25 \% \mathrm{PEOIPVA}$ ratio

)that was attributed to its miscibility. This miscibility associated with (Hydrogen bonds) between (Hydroxyl group) in PVA, and PEO, whereas there were two glass transition temperature for the blends ratio more than $30 \%$ PEO, that was due its immiscibility. The results proved increase in glass transition temperature $(\mathrm{Tg})$ with PEO loading increase: whereas the melting point was fixed about $\left(\mathrm{Tm}=310^{\circ} \mathrm{C}\right)$. TGA results showed that PEO loading caused overlapping between degradation stages ,and shifting in the second stage to higher degradation temperature, that was due to the good PVA, and PEO compatibility, and thermal stability improved of polymer blends. The mechanical properties of the samples involved were studied it was found that the tensile strength decreased with PEO ratio increase: whereas the elongation at break increased with PEO ratio . 25\% PEO/PVA proved better tensile strength than the others blend ratios and elongation-at-break values in comparison with that ratio more than $25 \%$, which was due to good miscibility. These results were enhanced with optical microscope and FTIR analysis. 25\% PEO/PVA was sellected to study the UV-Weathering effect on the mechanical properties according to its ultimate strength(26.67MPa) in comparision with the blends envolved.The stress strain curves for 25\% $\mathrm{PEO} / \mathrm{PVA}$ before and after UV-Weathering with periods of time $(25,60$,and $90 \mathrm{Hr}$.) showed little changes in ultimate strength up to $(60 \mathrm{Hr})$ exposure time,then there were little decrese in ultmate strength in $(90 \mathrm{Hr})$ exposure time . Ultimate tensile strength decrease was attributed to premature failur induced by polymer photo degradation. UV-Weathering caused yelowish of exposed samples that was due to long chain conjugated polymer sequencesbond formation induced by oxidative photo degradation. The results proved little changes within $(60 \mathrm{Hr})$,that was attributed to polymer stability.It was folowed by little changes in tensile strength and the elongation at break decreased that was due to sample brittlence increase,which was induced by irradiation, that caused modulus of elasticity increase. It was experimentally observed that the value of thermal conductivity of $(\mathrm{PVA}=0.099 \mathrm{~W} / \mathrm{cm} . \mathrm{K})$.The results proved decrease in thermal conductivity with PEO loading increase.
\end{abstract}

Key words: DSC, FTIR, Mechanical properties, PEO/PVA , TGA, UV-weathering.

\section{تاثير التعرض للاشعة فوق البنفجية على الخواص الميكانيكية للخلايط PEO/PVA}


قسم العلوم التطبيية، الجامعه التكنولوجيه ، بغداد، العراق

حضرت خلائط البولي فينيل الكحول البولي اثيلين كلاكيول(PVA/PEO ) وبمختلف التراكيز

بطريقة الاذابة, درست قابلية النماذج على الامتزاج والاستقراريه الحرارية للنماذج باستخدام مسعر المسح

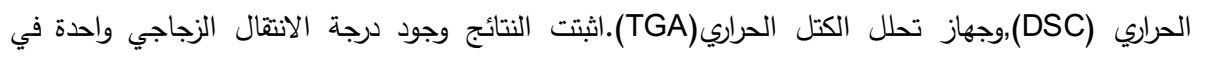

الخلائط الى حد النسبة (30\%PEO) واعزي ذلك الى القابلية على الامتزاج.اقترنت هذه القابلية على

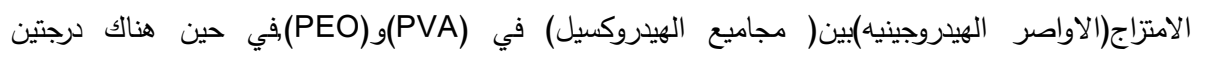

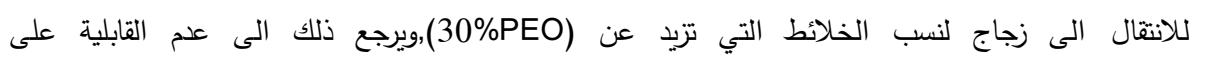

الامتزاج.اثتت النتائج زيادة في درجة الانتقال الى زجاج(Tg) بزيادة نسبة (PEO)رئي حين لوحظ ثبات درجة

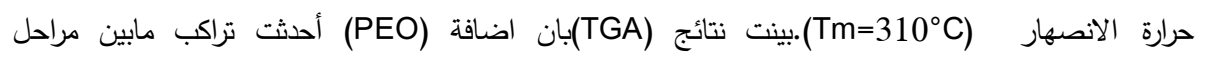

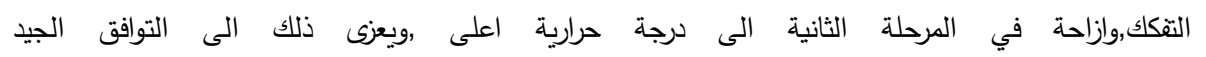

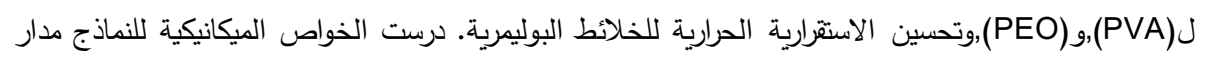

البحث :اظهرت النتائج تتاقص في متانة الثد بازدياد نسبة (PEO) 25\% من ناحية اخرى تزاد الاستطالة

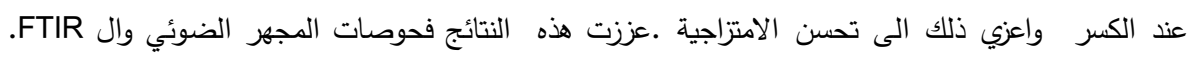

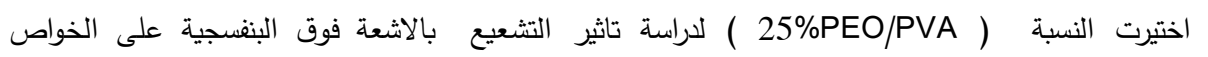

الميكانيكية كونها تمتلك اعلى متانة شد)مقارنة ببقية الخلائط..وجد من خلال منحيات

الاجهاد - المطاوعة قبل وبعد التعرض للاشعة فوق البنفجية للفترات الزمينية.(25,60,and 90Hr) للنسبة

(25\%PEO/PVA )

فترة التعرض(90Hr).تقل متانة الثد بتاثير التعرض للاشعة فوق البنفجية نتيجة لحدوث بداية للفشل ناجم

عن التفكك الضوئى للبوليمر .تسبب عملية التعرض للاشعة فوق البنفجية على اصفرار النماذج المتعرض لتصن

نتيجة لتكوين اواصر مزدوجة متعاقبة محتثة من خلال عملية التفكك الضوئي الموكسدان هذا التغير في

تركيب البوليمر يودي الى حدوث الى تغيرا ملحوظا في سلوك المادة الاساس(PVA).اثبتت النتائج تغيرات

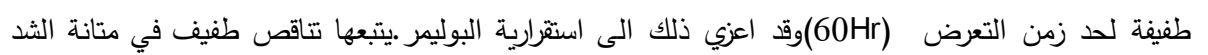

والاستطالة عند الكسر ويعود ذلك الى زيادة هشاشة النماذج بالتشعيع مما ادى الى زيادة معامل المرونة.

لوحظ ان التوصيليه الحرارية (PVA= 0.099W/cm.K). اظظهرت النتائج تتاقص في التوصيلية الحرارية

\section{Introduction}

بازياد نسبة (PEO).

Polymer science advances have led to novel delivery systems development. The introduction of new polymers has required to unique polymers properties improvement.. Polymers properties, which enhanced drugs release were solubilisers, stabilizers and mechanical properties[1]. Biodegradable, non-biodegradable applications of water soluble polymers have a broad range in the industry like food, pharmaceuticals paint, textiles, paper, constructions, adhesives, coatings, water treatment, etc[1,2]. Polyvinyl alcohol (PVA) structure contains of hydroxyl, and acetate groups, which influences on crytallizability and solubility of PVA [3]. PVA water solubility dependence is on PVA hydrolysis, molecular weight of the material, and solution temperature [4,5]. PVA hydro gels have been used in various biomedical and pharmaceutical applications because of its advantages, which are non-toxic, non-c arcinogenic, and bioadhesive in nature[5]. PVA proved a high degree of swelling in water (or biological fluids) and a rubbery and elastic nature so it is used in drug- delivery applications [6].PEG is also named as polyethylene oxide (PEO) or polyoxyethylene (POE), according to its molecular weight. The PEG structure is explained by $\mathrm{H}-(\mathrm{O}-\mathrm{CH} 2-\mathrm{CH} 2) \mathrm{n}-\mathrm{OH}$. PEG, PEO, and POE refer to an oligomer or polymer of ethylene oxide. . PEG has referred to oligomers and polymers of a molecular mass less than 20,000 $\mathrm{g} / \mathrm{mol}$, PEO to polymers with a molecular mass more than 20,000 g/mol, and POE to a polymer of any molecular mass[7,8]. PEG and PVA and their blends among others have many applications like as packaging, cosmetics, and emulsifiers and adhesives, [9,10],because of its low cost ,and light weight[11-17]. . Blending is an easy and excellent method to obtain a new materials with tailored properties[18,19]. Many studies have take into account the potential to get new materials with improved properties for different applications. Abdel Tawab et al. 
[20] reported that $60 \%$ PEG/PVA blend can provide the best blend compatibility. Other found that PVA/PEG blends with a good film and reported that blends with $40 \%$ PEG ratio did not form a cast film that was attributed to phase separation [20]. PVA and PEG of weak mechanical properties that was considered the disadvantage of hydrophilic polymers[21]. The main aim of present work to prepare degradable polymer blends, the aliphatic polymers PEO and PVA, which are suitable to be utilized as drug delivery. PEO effects and UV-Exposure effects on mechanical properties of the PVA were investigated.

Materials and Methods:

White powder of (PVA) manufactured by (Barcelona Espana (Didactic)), and white powder of (PEO-6000,MW=8000000) of (BDH) England were used as a homopolymers, and distilled water as a solvent.Take (10g)of purified (PVA) , and dissolved in $(100 \mathrm{ml})$ of distilled water in water bath. Magnetic stirrer was used , and the heat raised (from room temperature to $\left(90^{\circ} \mathrm{C}\right.$ ) till get the homogenous solution. Then the solution was gradually cooled to room temperature with continuously stirring.It was transferred on clean flat plat, and left it to dry. PEG/PVA blend films preparation followed the previous procedure of purified PVA ; through cooling process PEO addition at different concentration of $(25,30,40$,and $50 \mathrm{wt} \%)$ with continuously stirring. DSC was carried out using a STAPT(1000) from Linsies Germany. The heating rate was $\left(10^{\circ} \mathrm{C} / \mathrm{min}\right)$.TGA was performed from $\left(20-600^{\circ} \mathrm{C}\right)$ at heating rate of $\left(10^{\circ} \mathrm{C} / \mathrm{min}\right)$; the weight of the sample was $(20 \mathrm{mg})$. It was used tensile machine of (LARYEE-50kN,China) to determined the mechanical properties of the samples involved (ultimate tensile strength(UT), elongation(El\%), and young modulus(E).The samples were cut according to ASTM (D-638)standard, the speed of cross head was $(5 \mathrm{~mm} / \mathrm{min})$, and the test was done at room temperature. FTIR analysis was carried out using (SHMADZU-8400S)FTIR spectrometer (Japan) within range of $\left(400-4000 \mathrm{~cm}^{-1}\right)$. The morphology of PVA ,PEG/PVA blends at different ratios were studied by using optical microscope of Carl Zeiss company with magnification(X100).

\section{Results and discussion:}

\section{Effect of PEO Loadings on PVA/PEG Blends :}

It was seen PEO solution was clear, and difficult in film casting, whereas good film could be formed by PVA addition. It was found that the films of ratio more than $40 \%$ were not acceptable due phase separation[18,20]. Whereas R. J. Sengwa Abd Alla et al. [19] reported that limited miscibility blends was obtained up to $30 \%$ [19]. It was obtained clear films up to $30 \%$ that was due to PEO and PVA miscibility, which was decreased with PEO ratio increase up ,and PVA/PEO blends incompatibility was observed [9]. These results were in a good agreement with[22-24].

\section{Thermal Properties:}

DSC thermo grams results for PVA, and (PEO/PVA) at different ratios of $(25 \%, 30 \%, 35 \%, 40 \%, 50 \%)$ were shown in Fige.s.1, and 2. The results proved that there was one glass transition temperature up to $30 \%$ PEO/PVA that was due to its miscibility. This miscibility was attributed to the (Hydrogen bonds) of PVA, that is between Hydroxyl group,and PEO, whereas there were two glass transition temperature for the blends ratio more than $30 \% \mathrm{PEO}$, that was due its immiscibility[24].It was seen that the films transparency less than30\%PEO were good, and it decreased upper than that ratio, that was attributed to form two phases and Separated domains, which was induced incompatibility due the poor separated phases adhesion, and lowered the crystanility[2528].

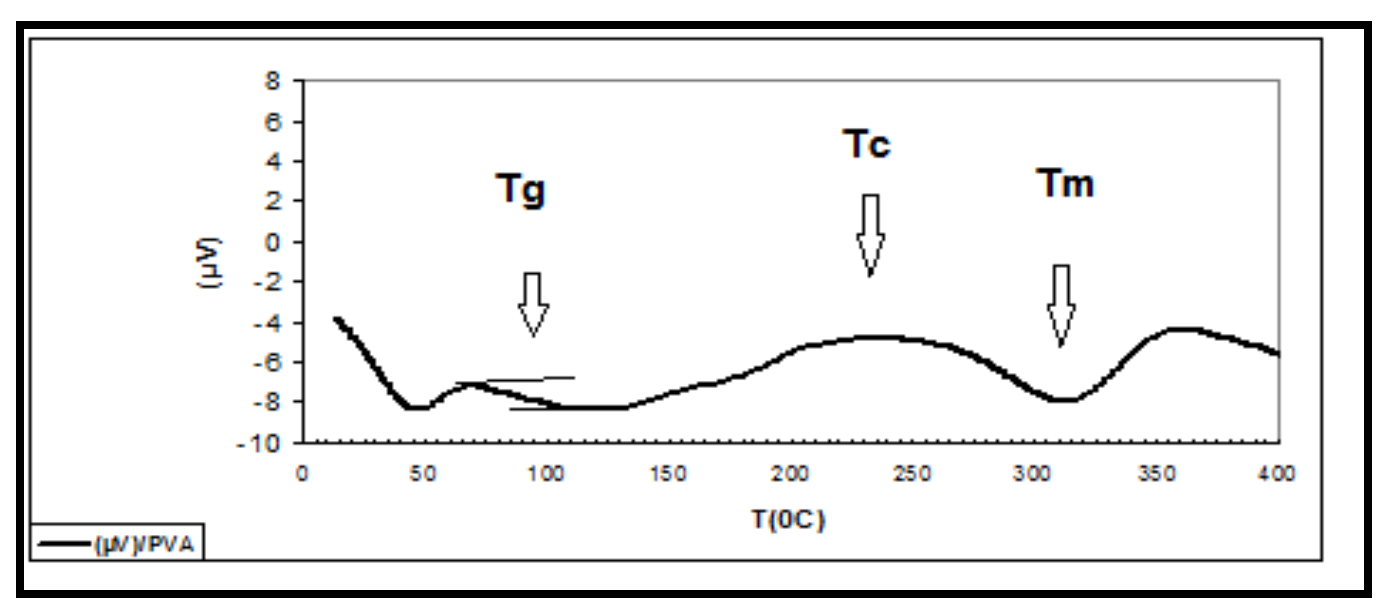


Figure 1-DSC PVA thermo gram shows its $\left(\mathrm{Tg}=85^{\circ} \mathrm{C}\right),\left(\mathrm{Tc}=240^{\circ} \mathrm{C}\right)$, and $\left(\mathrm{Tm}=310^{\circ} \mathrm{C}\right)$

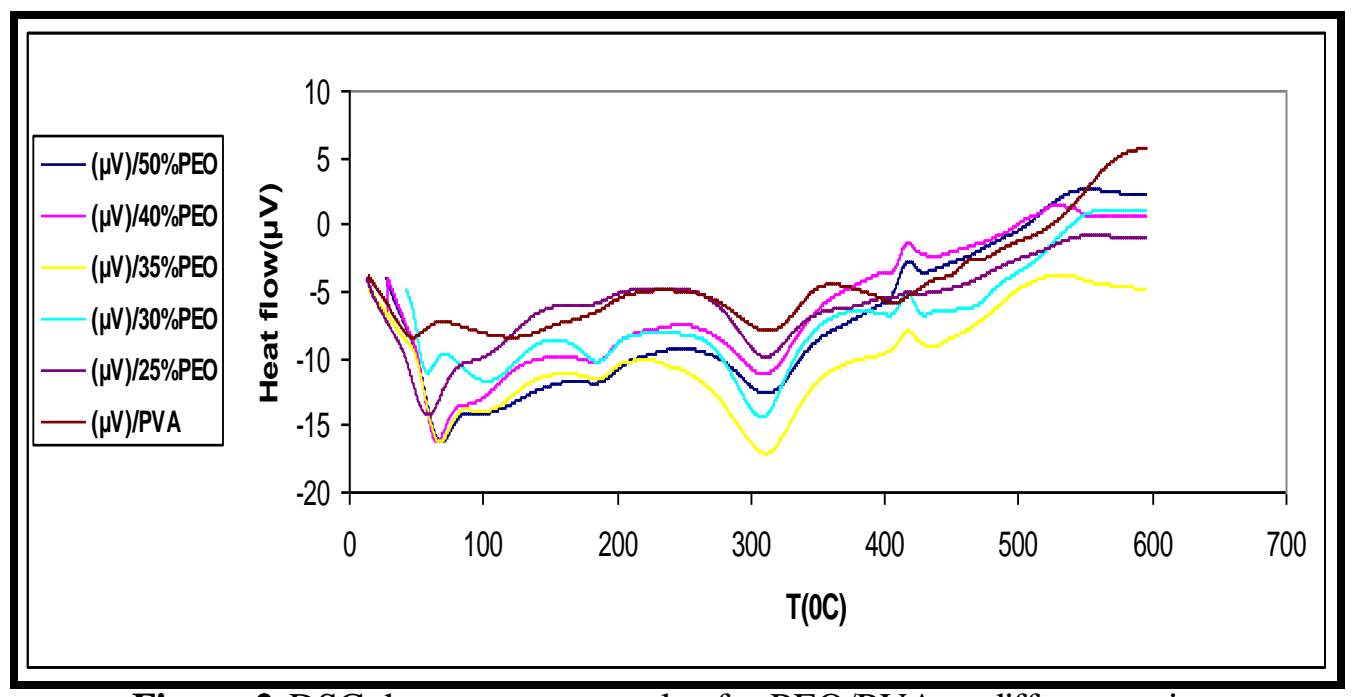

Figure 2-DSC thermo grams results for PEO/PVA at different ratios.

The results proved increase in (Tg) with PEO ratio increase :PVA is composed of two phases (crystalline and amorphous phases).Its behavior is complex during polymer heating process. It was found that the glass transition temperature for PVA was $\left(\mathrm{Tg}=85^{\circ} \mathrm{C}\right)$, that was attributed to relaxation process of main chain of polymer involved(Brownian motion), whereas the melting point was fixed about $\left(\mathrm{Tm}=310^{\circ} \mathrm{C}\right)$, that was in a good agreement with Fahad ,et als[29].Fig.3shows the Tg,Tc,and Tm changes with PEG ratio,see Table-1.

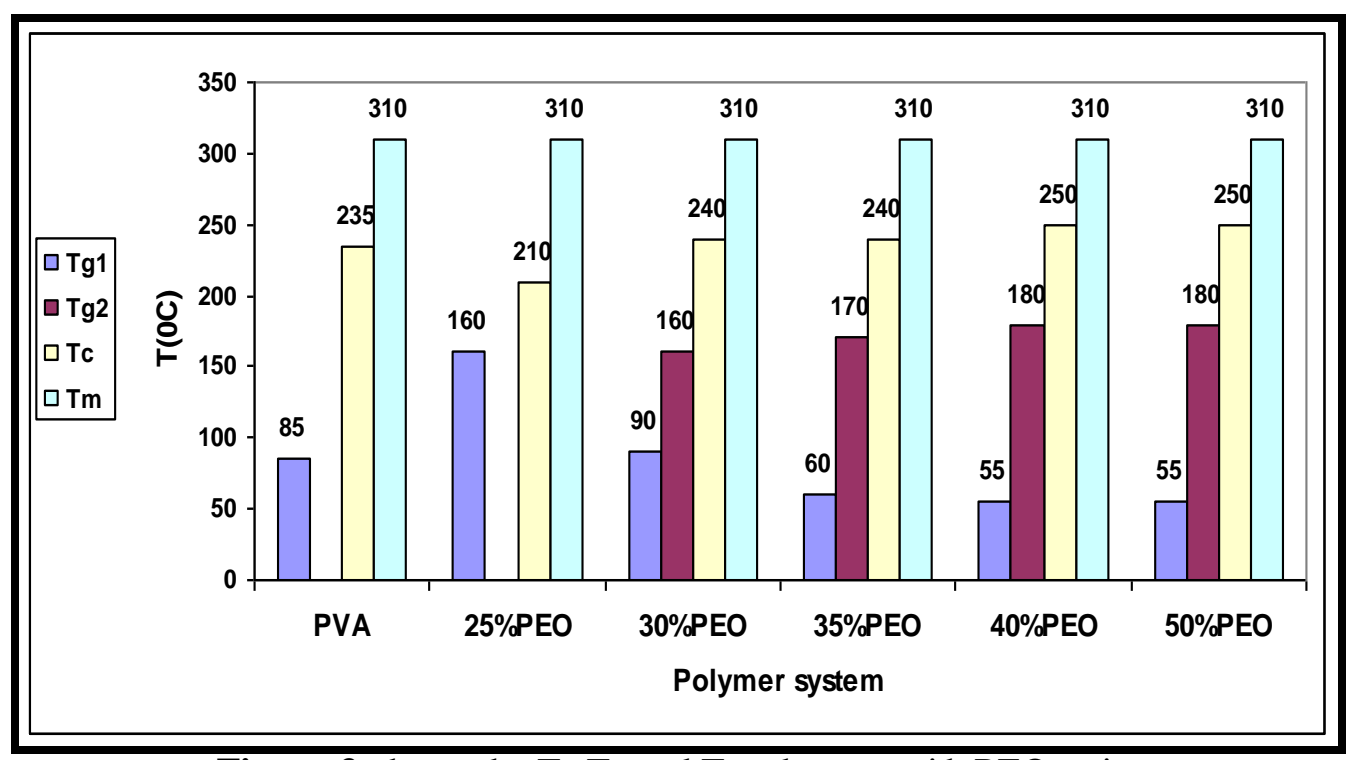

Figure 3-shows the $\mathrm{Tg}, \mathrm{Tc}$, and Tm changes with $\mathrm{PEO}$ ratio.

Table 1-shows the $\mathrm{Tg}, \mathrm{Tc}$,and $\mathrm{Tm}$ changes with PEO ratio.

\begin{tabular}{|c|c|c|c|c|}
\hline Polymer System & $\operatorname{Tm}\left({ }^{\circ} \mathbf{C}\right)$ & $\mathrm{Tc}\left({ }^{\circ} \mathrm{C}\right)$ & $\operatorname{Tg} 2\left({ }^{\circ} \mathrm{C}\right)$ & $\operatorname{Tg} 1\left({ }^{\circ} \mathrm{C}\right)$ \\
\hline PVA & 310 & 235 & ------------ & 85 \\
\hline $25 \%$ PEO & 310 & 210 & ----------- & 160 \\
\hline 30\% $\%$ PEO & 310 & 240 & 160 & 90 \\
\hline $35 \%$ PEO & 310 & 240 & 170 & 60 \\
\hline 40\% РEO & 310 & 250 & 180 & 55 \\
\hline $50 \%$ PEO & 310 & 250 & 180 & 55 \\
\hline
\end{tabular}


The thermal properties of PVA, and PEO/PVA at different ratios $(25 \%, 30 \%, 35 \%, 40 \%, 50 \%)$ are shown in Figure-4,and Figure-5,which represented the TGA results for the samples involved. The test was carried out by heating rate of $\left(10{ }^{\circ} \mathrm{C} / \mathrm{min}\right)$ within range of $\left(20-700{ }^{\circ} \mathrm{C}\right)$ by using Argon gas atmosphere.It was found stages number of thermal degradation of the samples involved depends on the polymer system. The first stage is attributed to the weight lose by water evaporation: This water represents the residual moisture, which is formed during sample preparation. The second stage corresponds to(side decomposition of the main chain), whereas the third stage is due to the(main chain decomposition )of the samples involved $[29,30]$ table.2. It was seen that first stage, and the second stage of PVA were within of $\left(215-374.978^{\circ} \mathrm{C}\right)$, and of $\left(374.978^{\circ} \mathrm{C}-595.43^{\circ} \mathrm{C}\right)$ thermal ranges irrespectively, whereas for $30 \% \mathrm{PEO} / \mathrm{PVA}$ it was seen that the first stage was within thermal range of $\left(140-376.779^{\circ} \mathrm{C}\right)$, and the second was within thermal range of $\left(376.779-595.32^{\circ} \mathrm{C}\right)$. The results proved three stages for $25 \%$ PEO/PVA at $\left(80-245.073^{\circ} \mathrm{C}\right),\left(245.073-377.755^{\circ} \mathrm{C}\right)$, and $(377.755-$ $595.075^{\circ} \mathrm{C}$ ) in respectively. The results also proved three stages for 50\% PEO/PVA, which were (50$\left.232^{\circ} \mathrm{C}\right),\left(232-377.028^{\circ} \mathrm{C}\right)$, and $\left(377.028-593.239^{\circ} \mathrm{C}\right)$ in respectively . The differences in stage number is due to evaporation stage disappearance. It was found that the thermal degradation initiation temperature was lowered with PEO ratio increase due to interface degradation [31,32]. The PEO addition caused overlapping between degradation stages ,and shifting in the second stage to higher degradation temperature, that was attributed to the good compatibility of PVA, and PEO, and thermal stability improved of polymer blends Figs..4,and 5,table.2. Figures- (4,and 5)showed the TGA curves for PVA,and $\mathrm{PEO} / \mathrm{PVA}$ blends at different ratio.It can be seen three stages in polymer films degradation. First stage was related with water evaporation,which was occurred up to around $\left(140^{\circ} \mathrm{C}\right.$ ),the second ,and third were attributed to sid and main chain degradation irrespectively [29,30]. For PVA, it was observed that the major degradation within range of $\left(215-374.978^{\circ} \mathrm{C}\right)$. The thermal stability of PEO is more than that of PVA[32-34].The results proved the weight loss rate decreased with the increase in PEO ratio increase that was attributed to H-bonds formation between PVA,PEO segments resulting in weight loss decrease(stability improvement)[31,35].It was found that PEO addition caused lower the residue value. It was noticed that the PEO ratio increase up to $30 \%$ resulted in lower loss rate. The blends tend to be brittle due to phase separation and less compatibility. These results in a good agreement weak mechanical properties, which would be discussed below.

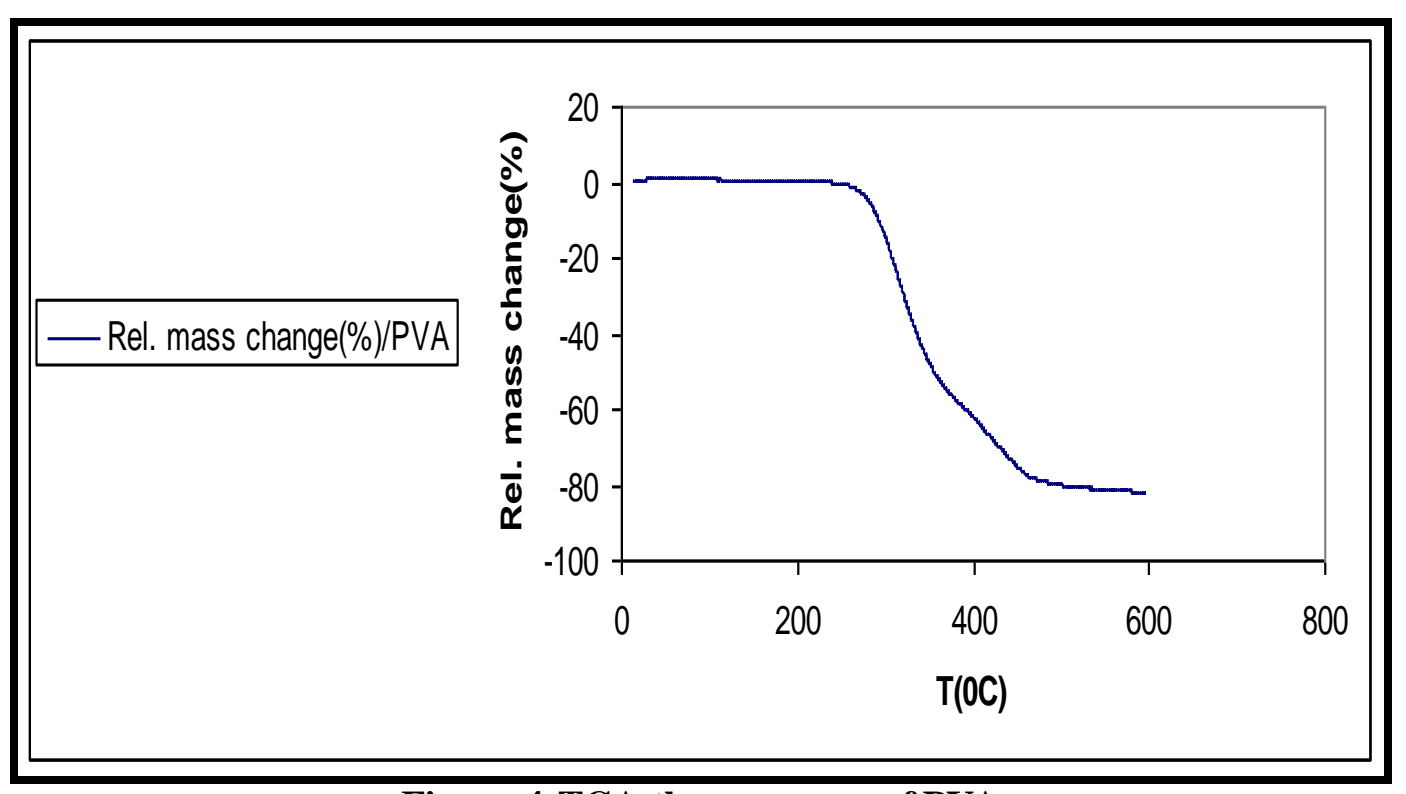

Figure 4-TGA thermo gram of PVA 


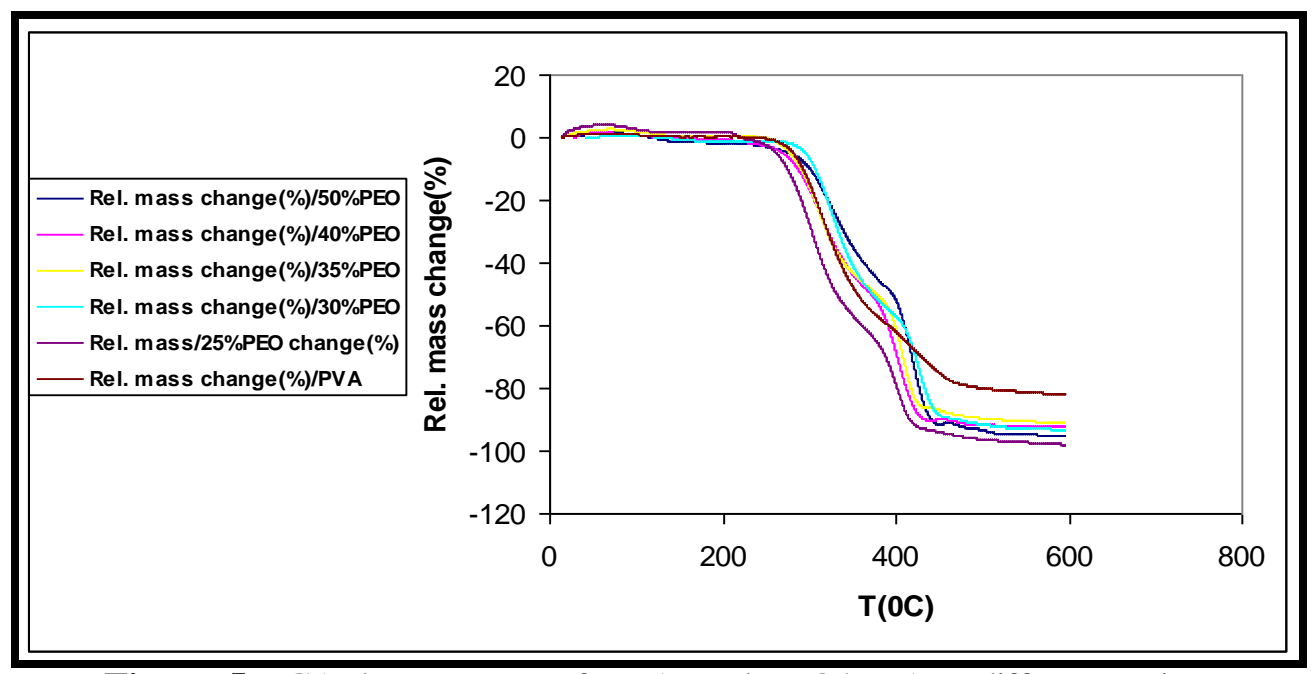

Figure 5-TGA thermo gram of PVA, and PEO/PVA at different ratios.

Table 2-The maximum weight loss rates of PVA and its blends at different PEO loadings

\begin{tabular}{|c|c|c|c|c|c|c|}
\hline $\begin{array}{c}\text { Polymer } \\
\text { System }\end{array}$ & $\begin{array}{l}\text { Stage } 1 \\
\mathbf{T}\left({ }^{\circ} \mathbf{C}\right)\end{array}$ & $\begin{array}{c}\text { Rel.mass } \\
\text { changes } \\
(\%)\end{array}$ & $\begin{array}{c}\text { Stage 2 } \\
\mathbf{T}\left({ }^{\circ} \mathbf{C}\right)\end{array}$ & $\begin{array}{c}\text { Rel.mass } \\
\text { changes } \\
(\%)\end{array}$ & $\begin{array}{c}\text { Stage3 } \\
\mathbf{T}\left({ }^{\circ} \mathbf{C}\right)\end{array}$ & $\begin{array}{c}\text { Rel.mas } \\
\text { s } \\
\text { changes } \\
(\%)\end{array}$ \\
\hline PVA & $\begin{array}{c}215- \\
374.978 \\
\end{array}$ & $\begin{array}{c}- \\
56.563 \%\end{array}$ & 374.978-595.43 & $-25.77 \%$ & - & \\
\hline $25 \%$ PEO & $\begin{array}{c}80- \\
237.385\end{array}$ & $-5.129 \%$ & $\begin{array}{l}\text { 237.385- } \\
\text { 375.475 }\end{array}$ & $-63.4107 \%$ & $\begin{array}{l}375.475- \\
595.264\end{array}$ & $\begin{array}{c}- \\
33.684 \%\end{array}$ \\
\hline $30 \%$ PEO & $\begin{array}{c}140- \\
376.779 \\
\end{array}$ & $\begin{array}{c}- \\
55.395 \% \\
\end{array}$ & $\begin{array}{c}\text { 376.779- } \\
595.32 \\
\end{array}$ & $-36.66 \%$ & & \\
\hline $35 \%$ PEO & $\begin{array}{c}80- \\
245.073 \\
\end{array}$ & $-2.702 \%$ & $\begin{array}{l}\text { 245.073- } \\
\text { 377.775 } \\
\end{array}$ & $-50.011 \%$ & $\begin{array}{l}377.775- \\
\mathbf{5 9 5 . 0 7 5} \\
\end{array}$ & $\begin{array}{c}- \\
41.135 \% \\
\end{array}$ \\
\hline 40\% РEО & $\begin{array}{c}50- \\
370.834 \\
\end{array}$ & $\begin{array}{c}- \\
51.791 \% \\
\end{array}$ & $370.834-592.23$ & $-42.199 \%$ & --- & \\
\hline $50 \%$ PEO & $50-232$ & $-4.327 \%$ & $232-377.028$ & $-45.465 \%$ & $\begin{array}{l}\text { 377.028- } \\
593.239\end{array}$ & $\begin{array}{c}- \\
47.307 \% \\
\end{array}$ \\
\hline
\end{tabular}

\section{Mechanical properties:}

\section{PEO addition effect on PVA/PEG Blends}

PVA , PEO/PVA at different ratios(25,30,35,40,and 50\%) mechanical properties were investigated including of tensile strength, elongation, and modulus of elasticity, which were calculated from the related stress strain curves. The obtained results were shown in table.3. The results proved the tensile strength decrease in comparison with pure PVA that was attributed to PEO brittleness. These results were in a good agreement with other reported findings[19,35].This decrease was due to the PEO plasticizing effect in comparison pure PVA matrix[36].Fig.6. Elongation at break, and tensile strength proved increase at $25 \% \mathrm{PEO} / \mathrm{PVA}$,that was due to miscibility improvement[32]. That results enhanced DSC results. For the blend ratio more than $30 \%$ it was seen brittle induced by phase separation (immiscibility) due to PEO addition. These results were enhanced with optical micrographs, which proved increase in porous size and phase separation(immiscibility) with PEO addition increase more than $30 \%$. That caused in a significant decrease in the tensile strength and the elongation at break Figs.7to9[33]. 


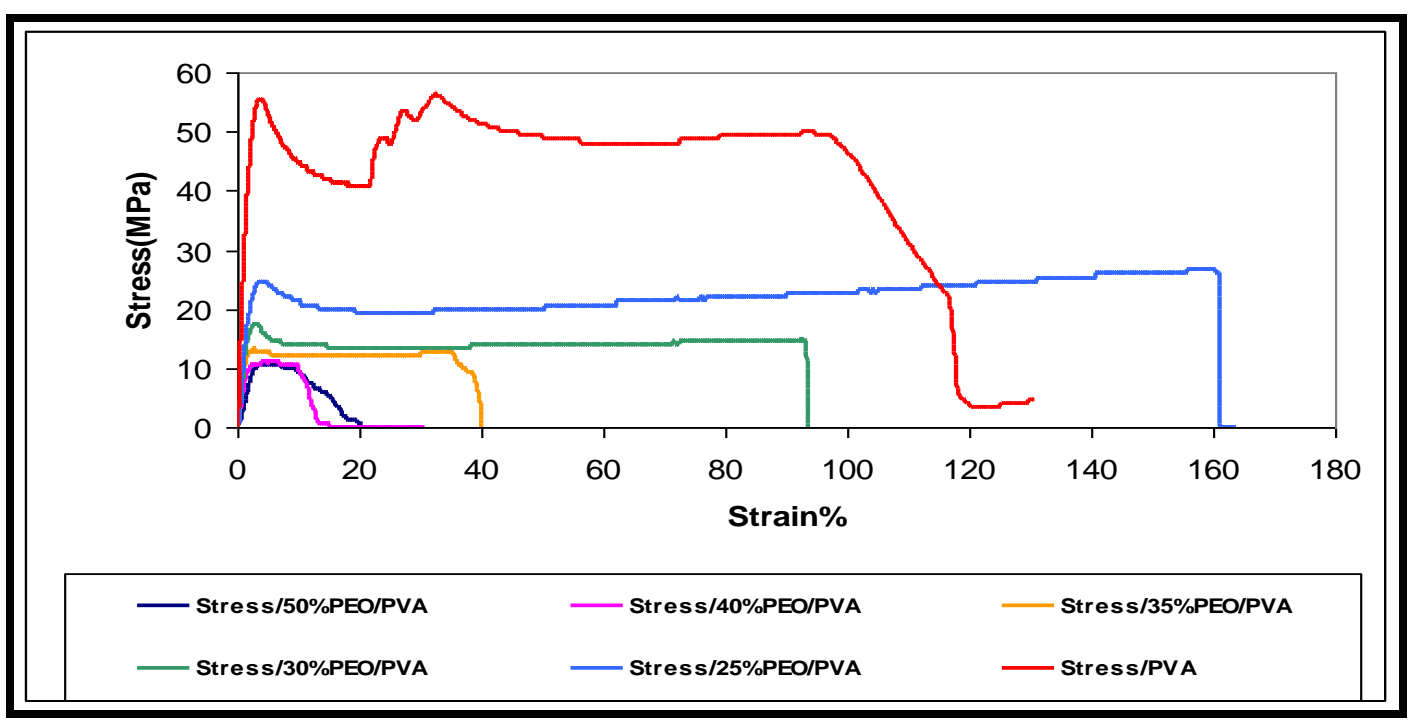

Figure 6 -Stress-strain curves for PVA before and after PEO loading with different ratios

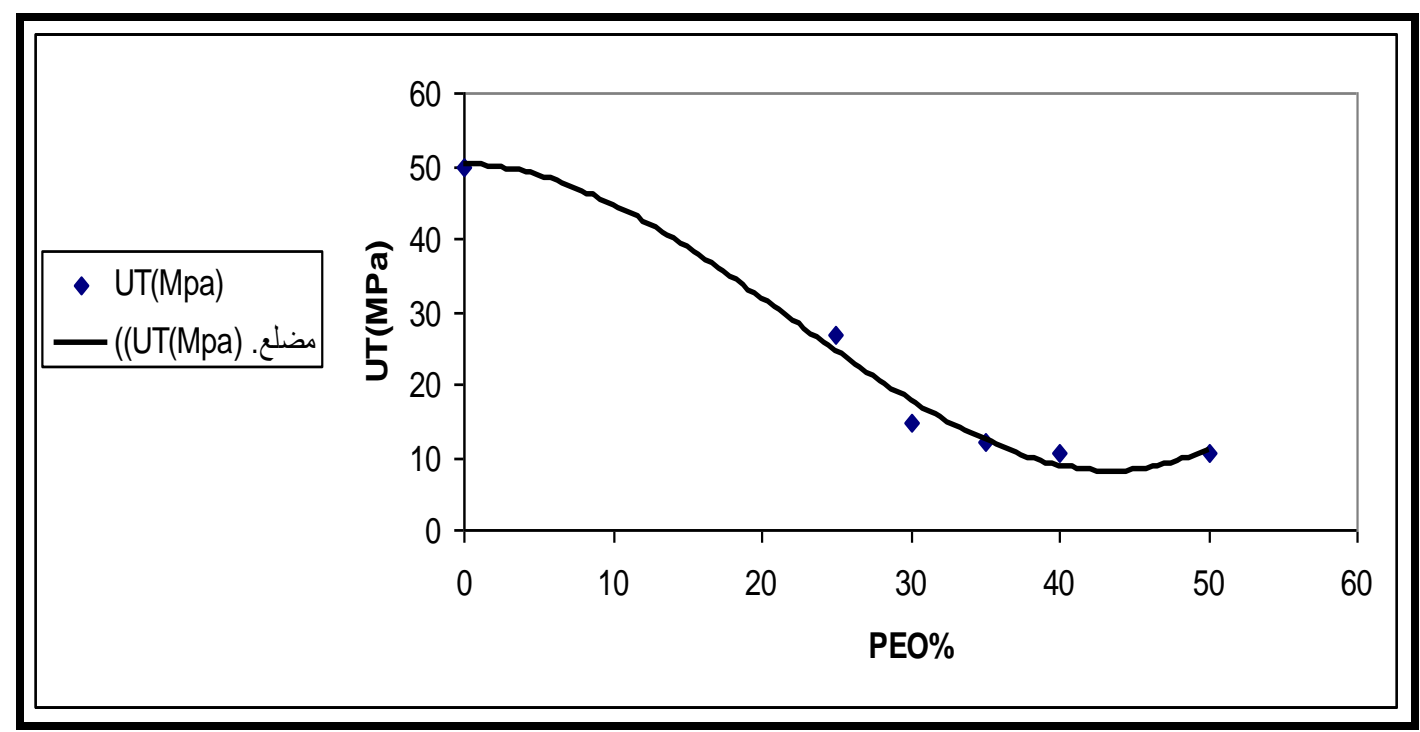

Figure 7-Ultimate strength for PVA before and after PEO loading with different ratio

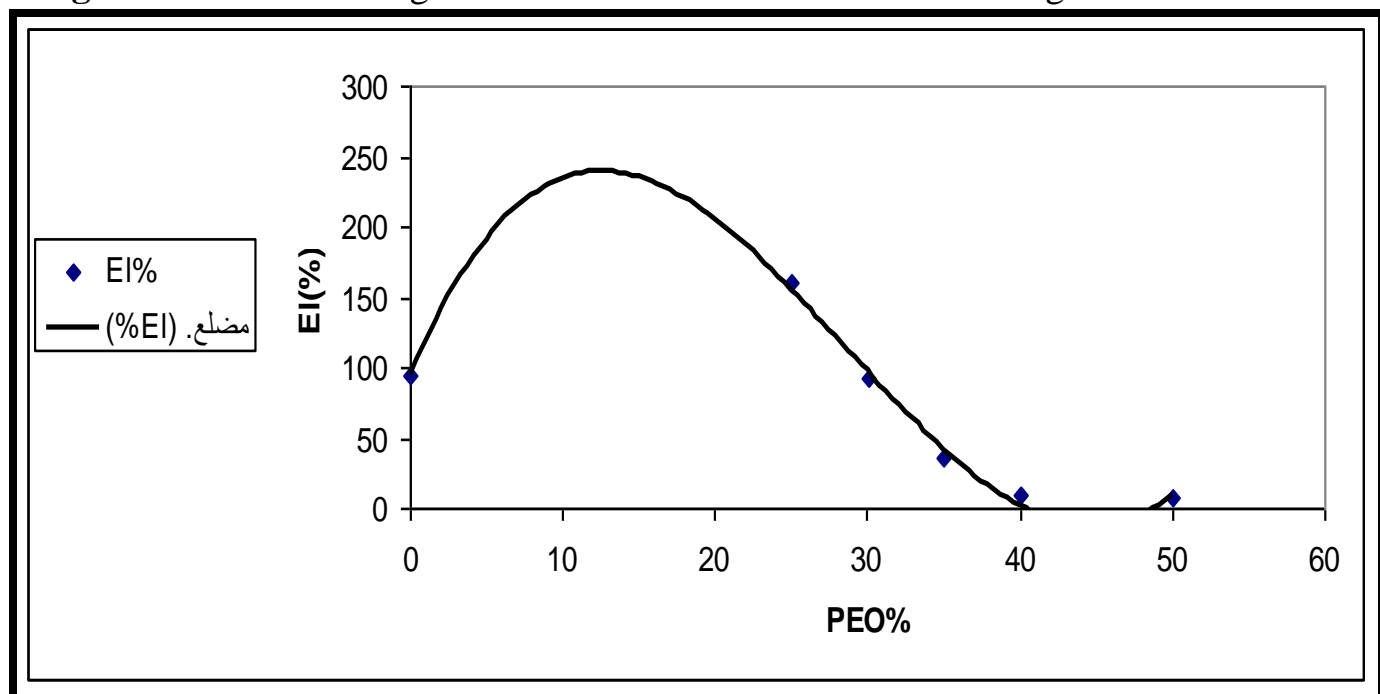

Figure 8-Elongation - at break for PVA before and after PEO loading with different ratios. 


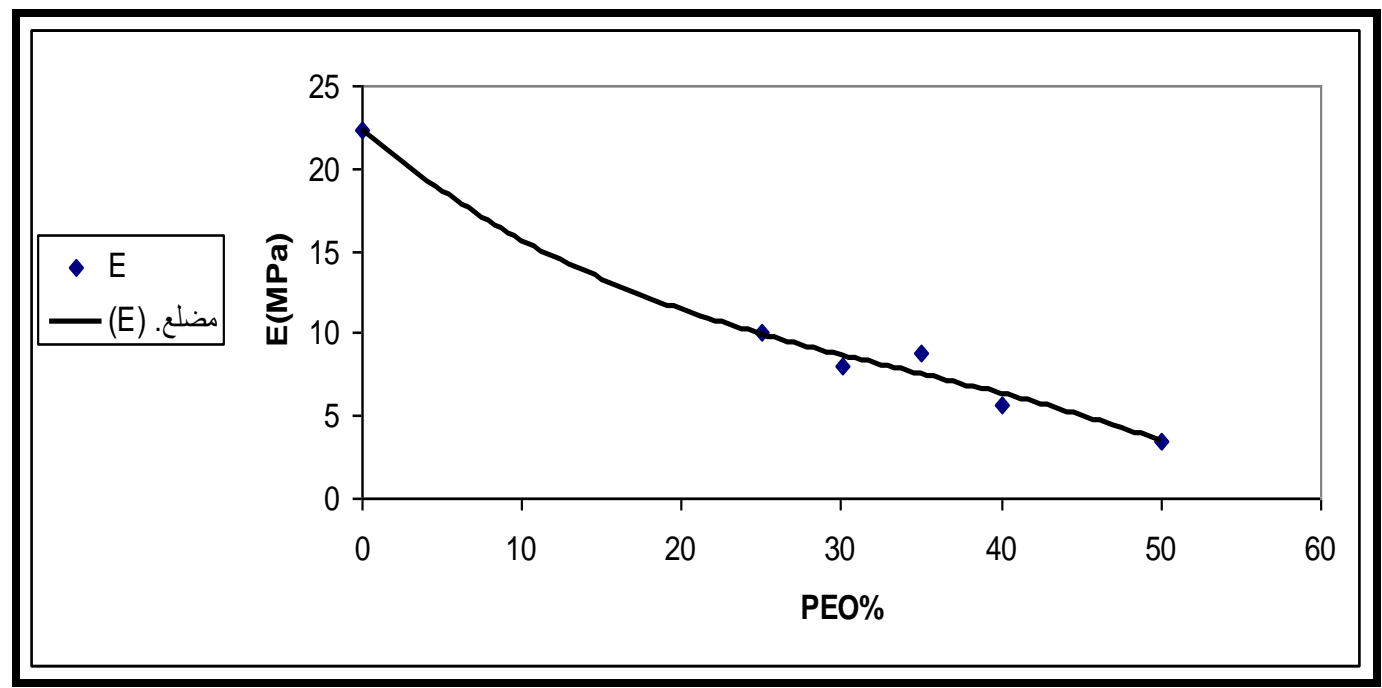

Figure 9-Modulus of elasticity for PVA before and after PEO loading with different ratios.
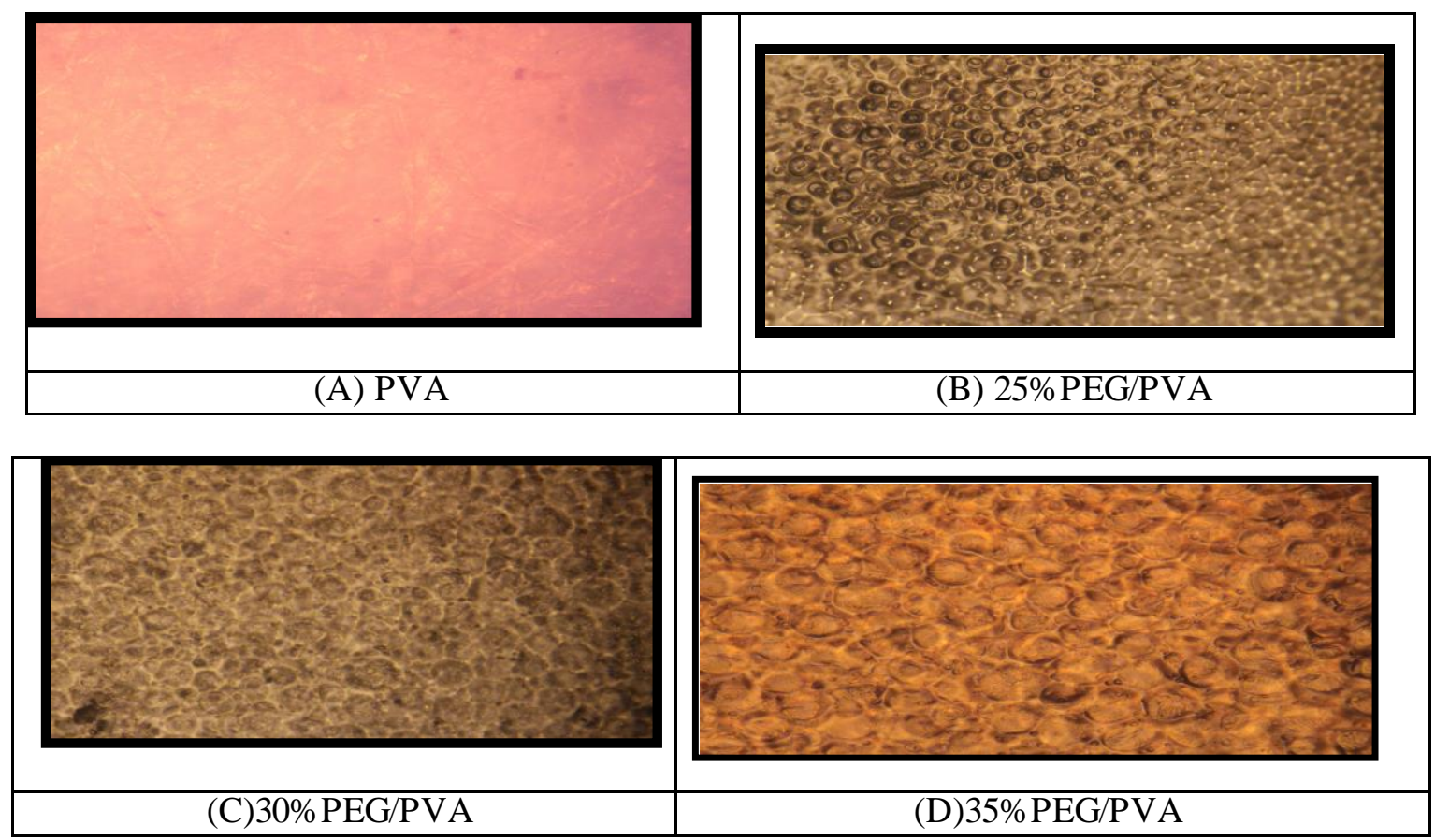

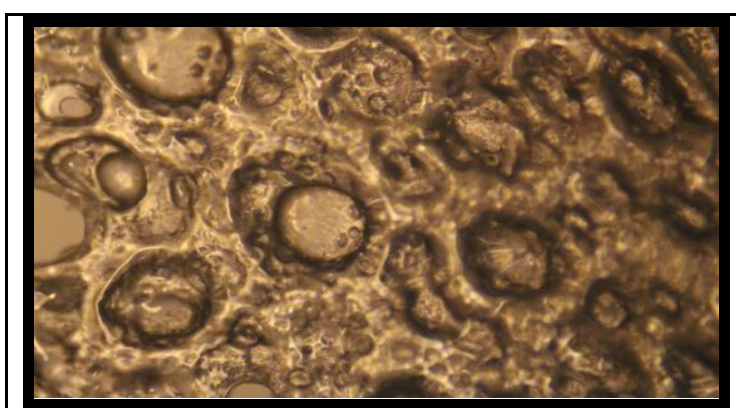

(E)40\%PEG/PVA

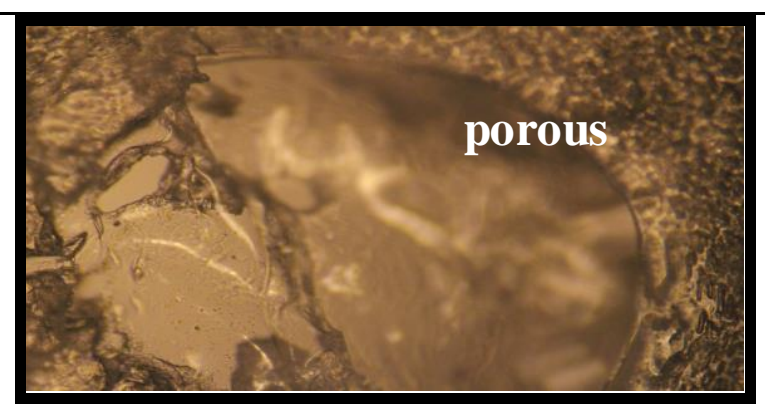

(F) $50 \%$ PEG/PVA

Figure 10 - Optical micrographs for PVA before and after PEO loading with different ratios(X100). 


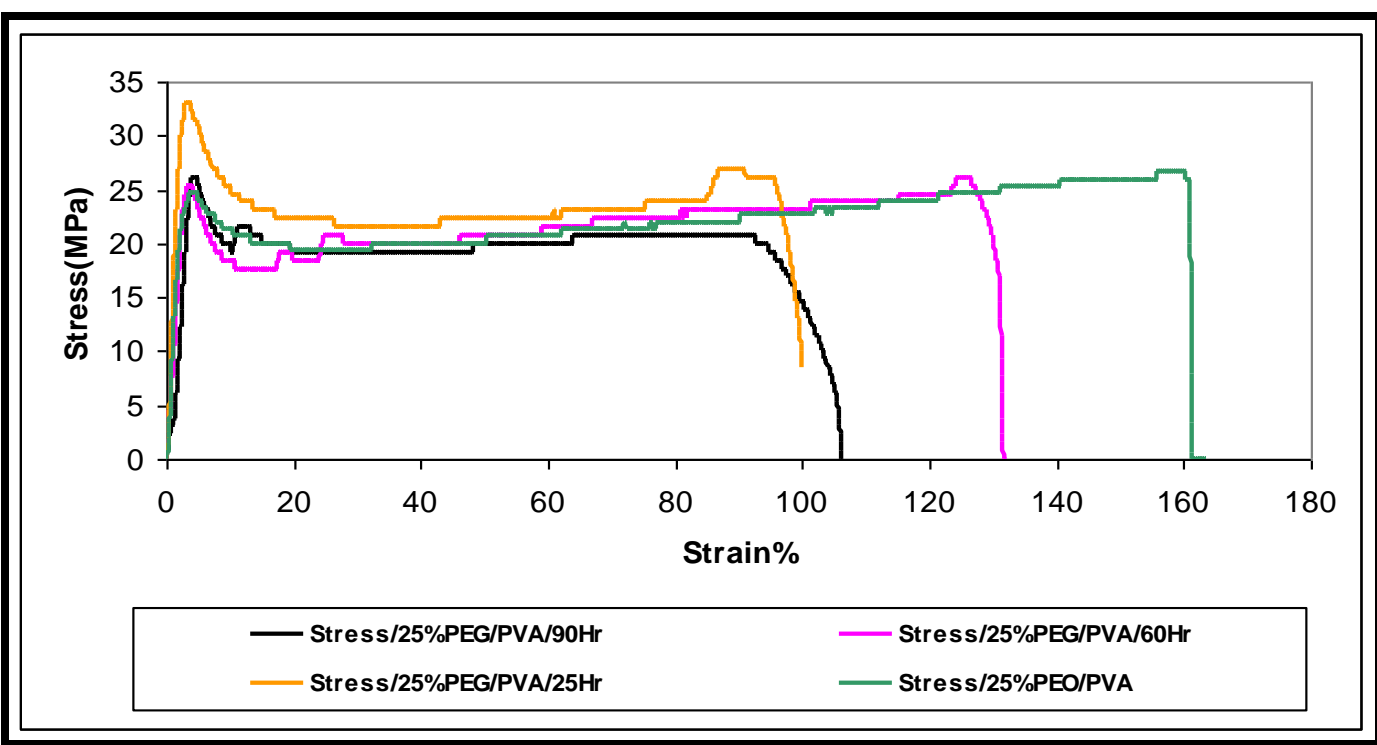

Figure 11 -Stress-strain curves for 25\%PEO/PVA before and after UV-Weathering with different time $(25,60$,and $90 \mathrm{Hr}$.).

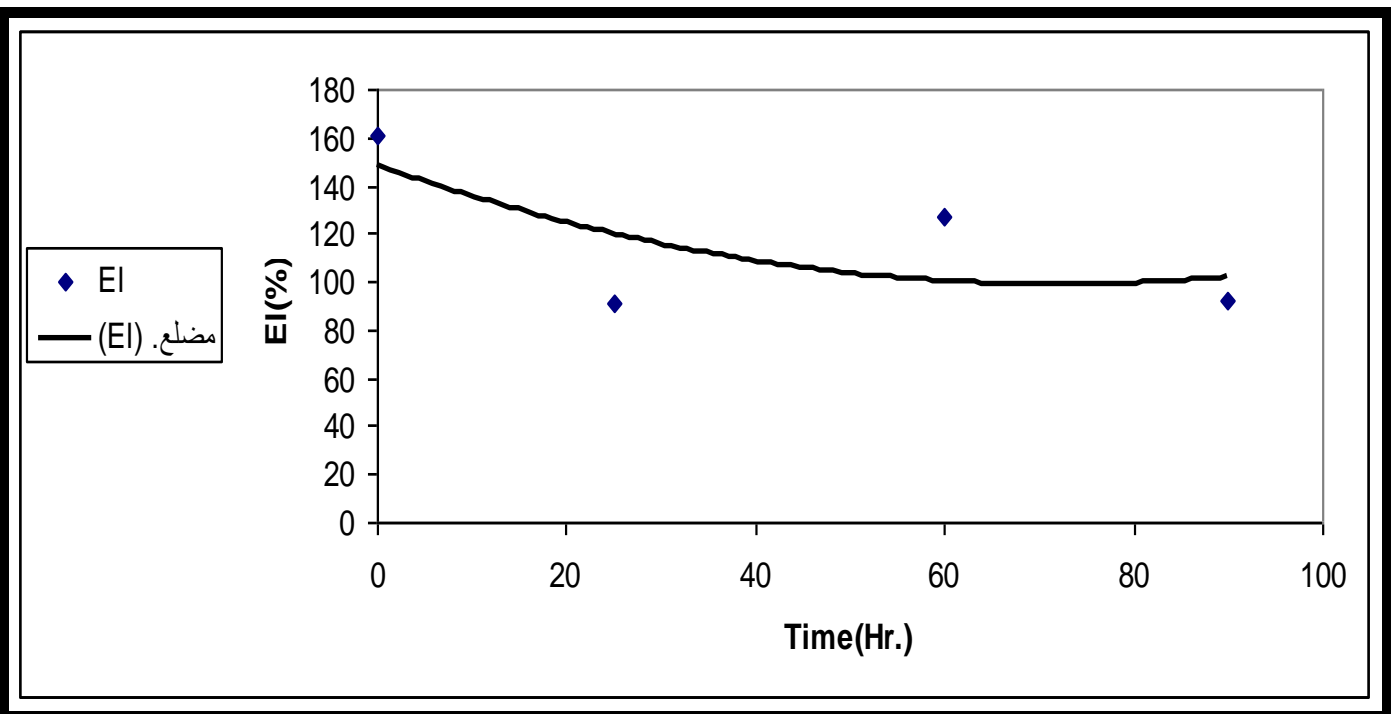

Figure 12 -Elongation-at break for 25\%PEO/PVA before and after UV-Weathering with different time $(25,60$,and $90 \mathrm{Hr}$.).

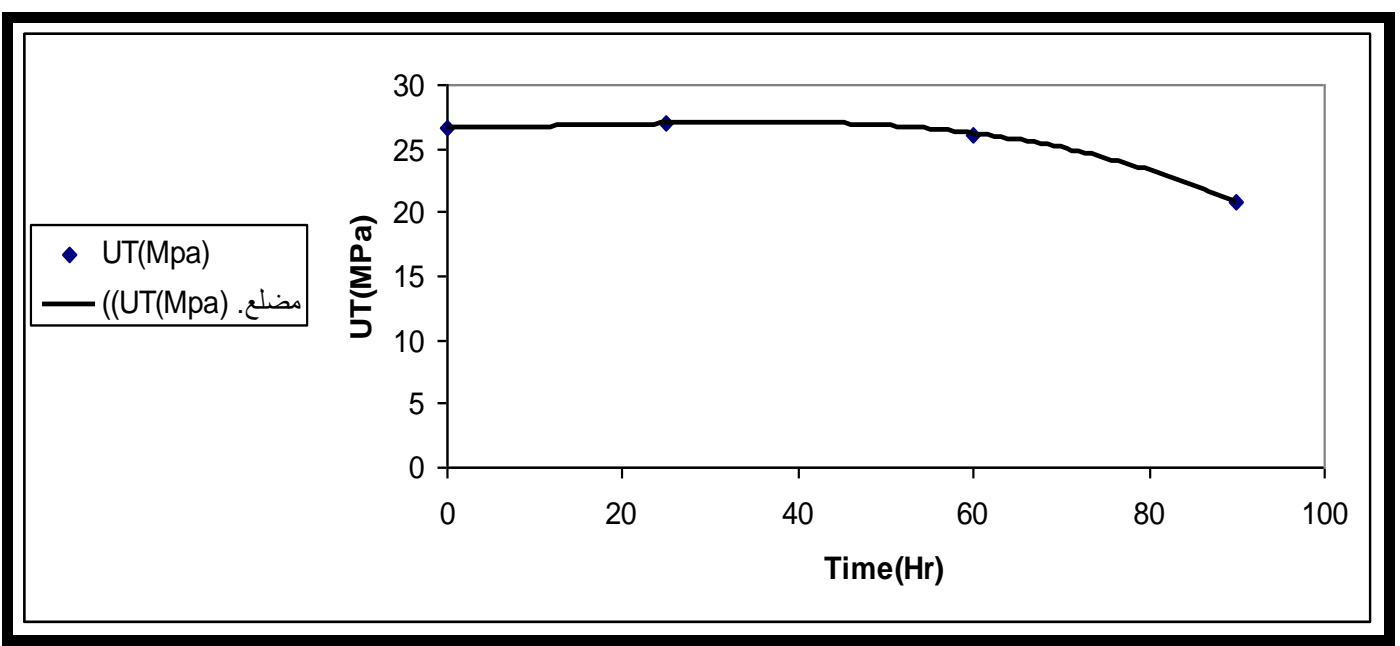

Figure 13- Ultimate strength for 25\%PEO/PVA before and after UV-Weathering with different time $(25,60$,and $90 \mathrm{Hr}$.). 


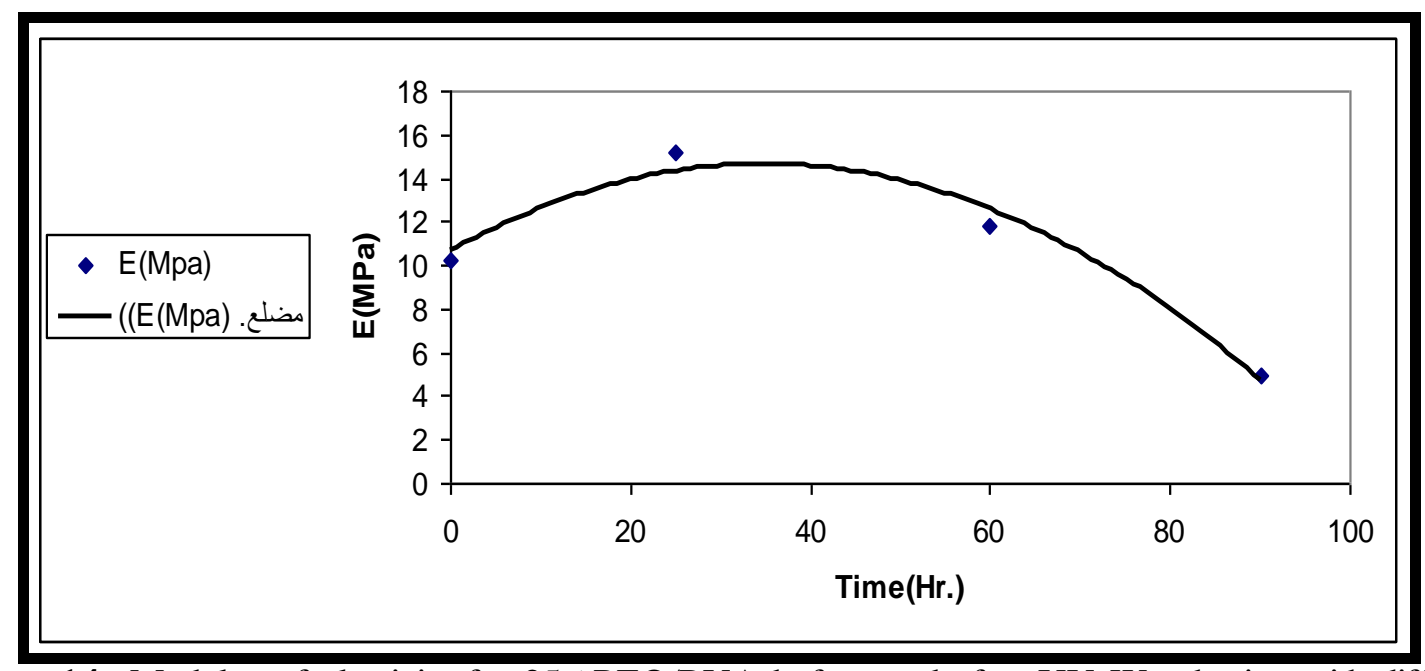

Figure 14- Modulus of elasticity for 25\%PEO/PVA before and after UV-Weathering with different time $(25,60$,and $90 \mathrm{Hr}$.).

Table 3-The meechanical properties of PVA,before and after PEO loading with different concentration.

\begin{tabular}{|c|c|c|c|}
\hline$\%$ & UT(MPa) & El\% & E(Pa) \\
\hline $\mathbf{0}$ & $\mathbf{5 0}$ & $\mathbf{9 4 . 2 5}$ & $\mathbf{2 2 . 3 5}$ \\
\hline 25 & $\mathbf{2 6 . 6 7}$ & $\mathbf{1 6 0 . 3 3}$ & $\mathbf{1 0}$ \\
\hline 30 & 14.67 & $\mathbf{9 2 . 7 6}$ & $\mathbf{8}$ \\
\hline 35 & 12 & $\mathbf{3 5 . 6 8}$ & $\mathbf{8 . 7 5}$ \\
\hline 40 & 10.67 & 9.9 & $\mathbf{5 . 6}$ \\
\hline 50 & 10.67 & $\mathbf{7 . 2 8}$ & $\mathbf{3 . 5 3}$ \\
\hline
\end{tabular}

\section{UV-Exposure effect on $25 \%$ PEO/PVA blend mechanical properties of :}

25\% PEO/PVA was sellected to study the UV-Weathering effect on the mechanical properties according to its ultimate strength in comparision with the blends envolved[38].Fig.11 shows stress strain curves for $25 \% \mathrm{PEO} / \mathrm{PVA}$ before and after UV-Weathering with periods of time $(25,60$, and 90Hr.).It was seen little changes in ultimate strength up to $(60 \mathrm{Hr})$ exposure time,then there were little decrese in ultmate strength in $(90 \mathrm{Hr})$ exposure time[39]. Ultimate tensile strength decrease was attributed to premature failur induced by polymer photo degradation[40]. UV-Weathering caused yelowish of exposed samples that was due to long chain conjugated polymer sequencesbond formation induced by oxidative photo degradation .This changes in polymer structure resulted in signficiant changes in aging behavior of matrix material (PVA)[41]. As results of photodegradation, carbonyl and hydroperoxides were formed.Hydroperoxides induced autodegradation in polymer chain and affected in polymer properties changes by autocattylic free radical formation. The results proved little changes within (60Hr), that was attributed to polymer stability[38-41].It was little changes in tensile strength and the elongation at break decreased that was attributed to increas in sample brittlence by irradiation, which caused modulus of elasticity increase,that was in a good agreement with Sameer A. Awad ,Eman M. Khalaf[42 ].See Figs.12 to 14.

Table 4-The meechanical properties 25\% PEO/PVA blend before and after UV-Exposure with different time.

\begin{tabular}{|c|c|c|c|}
\hline Time(Hr) & UT(Mpa) & El\% & E(Mpa) \\
\hline 0 & 26.67 & 160.67 & 10.26 \\
\hline 25 & 26.92 & 90.75 & 15.24 \\
\hline 60 & 26.15 & 126.57 & 11.76 \\
\hline 90 & 20.77 & 92.54 & 5 \\
\hline
\end{tabular}

\section{Fourier Transformation Infrared Analysis:}

Fig. 15 showed the characteristic bands of PVA at $(840.99,1421,1579.75,3462.34$, and 
$3497.06 \mathrm{~cm}-1)$.It was clear that the band at $840.99 \mathrm{~cm}-1$ was induced by functional group $\left(-\mathrm{CH}_{2}\right)$ stretching vibration. The band at $840.99 \mathrm{~cm}-1$ cooperated in functional group $(\mathrm{C}-\mathrm{O})$ stretching vibration. The bands at 1427 and $3349 \mathrm{~cm}-1$ were attributed to (C-C) stretching , and the functional group $(-\mathrm{OH})$ vibration in respectively. The bands within range of $(1579-1739.85) \mathrm{cm}-1$ was due to the functional group of $(\mathrm{C}=\mathrm{O})$ stretching vibration. Fig. 15 proved the same bands that the blend membranes did not possess. It was seen new bands appearance, and disappearance of others , and some bands were shifted, that was attributed to that was an evidence for correctly blending of the polymers involved. The bands at (1427 and 3349 ) $\mathrm{cm}-1$ became more smooth with the PEO addition. The characteristic band of PEO at (2808.45-2931.90) $\mathrm{cm}^{-1}$ in the blend samples spectra ,which was induced by functional group ( $-\mathrm{CH}_{2}$ ) stretching vibration. During film formation process, the hydrogen bond formation between ether bond, and hydroxyl group of PEO ,and PVA macromolecules irrespectively[44-45]. The intermolecular entanglement rate was increased by PEO addition that was caused by its long molecular chain and good viscoelasticity [46-49].

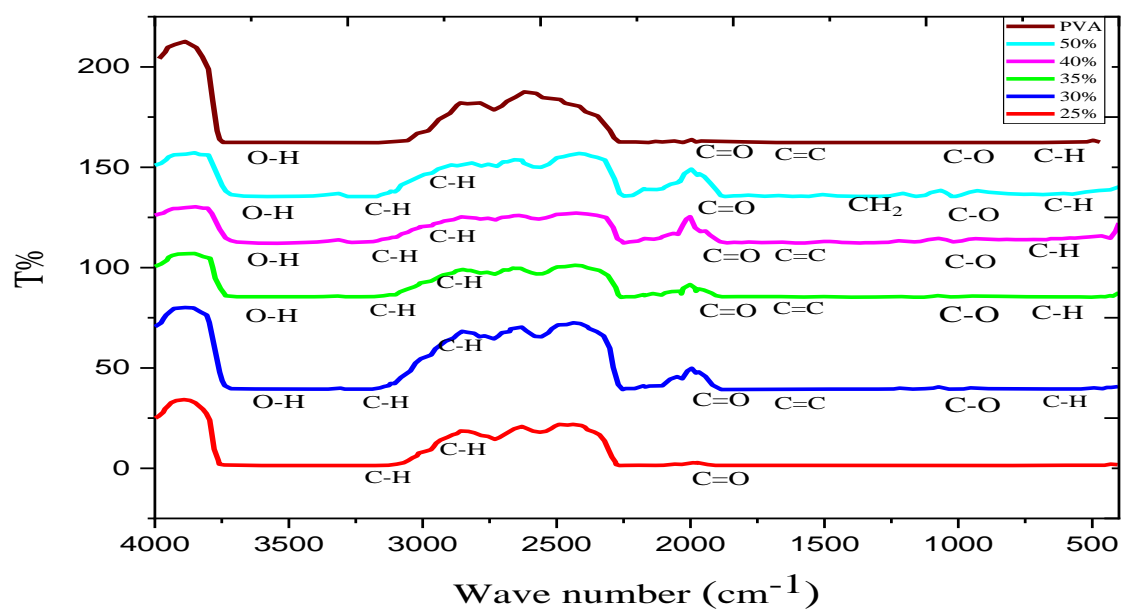

Figure 15-shows the FTIR spectra for PVA,and PEG/PVA blends at different concentration

Table 4-shows FTIR spectra characterization of PVA, and PEG/PVA blends at different concentration

\begin{tabular}{|c|c|c|c|c|c|c|c|c|}
\hline Samples & $\begin{array}{c}\text { C-H } \\
\text { OUT of } \\
\text { phase } \\
\text { bending } \\
600-900 \\
\text { cm- }^{1}\end{array}$ & $\begin{array}{c}\text { C-O } \\
\text { Stretching } \\
840-1100 \\
\mathrm{~cm}^{-1}\end{array}$ & $\begin{array}{c}\text { CH2 } \\
\text { bending } \\
1250- \\
1350 \\
\text { cm }^{-1}\end{array}$ & $\begin{array}{c}\text { C-C } \\
\text { Stretching }\end{array}$ & $\begin{array}{c}\mathrm{CH2} \\
\text { Stretching } \\
\& \\
\mathrm{C}=\mathrm{C} \\
\text { Wagging } \\
\begin{array}{c}1550-1600 \\
\mathrm{~cm}^{-1}\end{array}\end{array}$ & $\begin{array}{c}\mathrm{C}=\mathrm{O} \\
\text { Stretching } \\
1550-1800 \\
\mathrm{~cm}^{-1}\end{array}$ & $\begin{array}{c}\text { C-H } \\
\text { Stretching } \\
\text { aliphatic } \\
2800-3100 \\
\text { cm }^{-1}\end{array}$ & $\begin{array}{c}\text { Hydroxyl } \\
\text { S tretchin } \\
\text { g } 3400- \\
3600 \mathrm{~cm}^{-1}\end{array}$ \\
\hline PVA & 840.99 & 840.99 & ....... & 1421 & 1579.75 & $\begin{array}{l}1579.75 \\
1745.64 \\
1745.64\end{array}$ & ........ & $\begin{array}{l}3462.34 \\
3497.06\end{array}$ \\
\hline $25 \%$ & $\ldots \ldots$ & $\ldots \ldots$ & $\ldots \ldots$ & ........ & $\ldots \ldots$ & 1631.83 & 2808.45 & $\ldots \ldots$ \\
\hline $30 \%$ & 952.87 & 952.87 & & ......... & 1581.68 & $\begin{array}{l}1581.68 \\
1707.06 \\
1739.85 \\
\end{array}$ & 2823.88 & $\begin{array}{l}3481.63 \\
3568.43 \\
3587.72\end{array}$ \\
\hline $35 \%$ & $\begin{array}{l}852.56 \\
945.15\end{array}$ & $\begin{array}{l}852.56 \\
945.15\end{array}$ & $\ldots \ldots$ & 1469.85 & 1579.75 & $\begin{array}{l}1579.75 \\
1631.83 \\
1674.27 \\
1739.85 \\
\end{array}$ & 2906.82 & $\begin{array}{l}3394.83 \\
3549.14\end{array}$ \\
\hline $40 \%$ & $\begin{array}{l}607.60 \\
646.17 \\
678.97 \\
727.19 \\
844.85 \\
949.01 \\
\end{array}$ & $\begin{array}{l}844.85 \\
949.01\end{array}$ & $\ldots$. & & 1591.33 & $\begin{array}{l}1591.33 \\
1653.05 \\
1730.21\end{array}$ & 2931.90 & $\begin{array}{l}3365.90 \\
3396.76\end{array}$ \\
\hline
\end{tabular}




\begin{tabular}{|l|l|l|l|l|l|l|l|l|}
\hline $50 \%$ & 844.85 & 844.85 & \multirow{2}{*}{1354.07} & 1452.09 & $\ldots \ldots$ & 1649.19 & 2897.18 & 3398.69 \\
& 950.94 & 950.94 & & 1464.02 & $\ldots \ldots$ & 1734.06 & \\
\hline
\end{tabular}

\section{The rmal conductivity}

Figure-16 shows PEO effect on the thermal conductivity of PVA. It was experimentally observed that the value of thermal conductivity of $(\mathrm{PVA}=0.099 \mathrm{~W} / \mathrm{cm} . \mathrm{K})$. The results proved decrease in thermal conductivity with PEO loading increase. PVA thermal conductivity is controlled by phonon mean free path variation at room temperature. The mean free path for the amorphous PVA is very short due to the numerous defects induced by its amorphous PVA structure. The defect are formed during polymerization process like(chains bends, chains gap, and chain length variation[9,19]. The thermal conductivity decrease with PEO was due to phase separation porosity and porous size .These results were enhanced with optical micrographs.

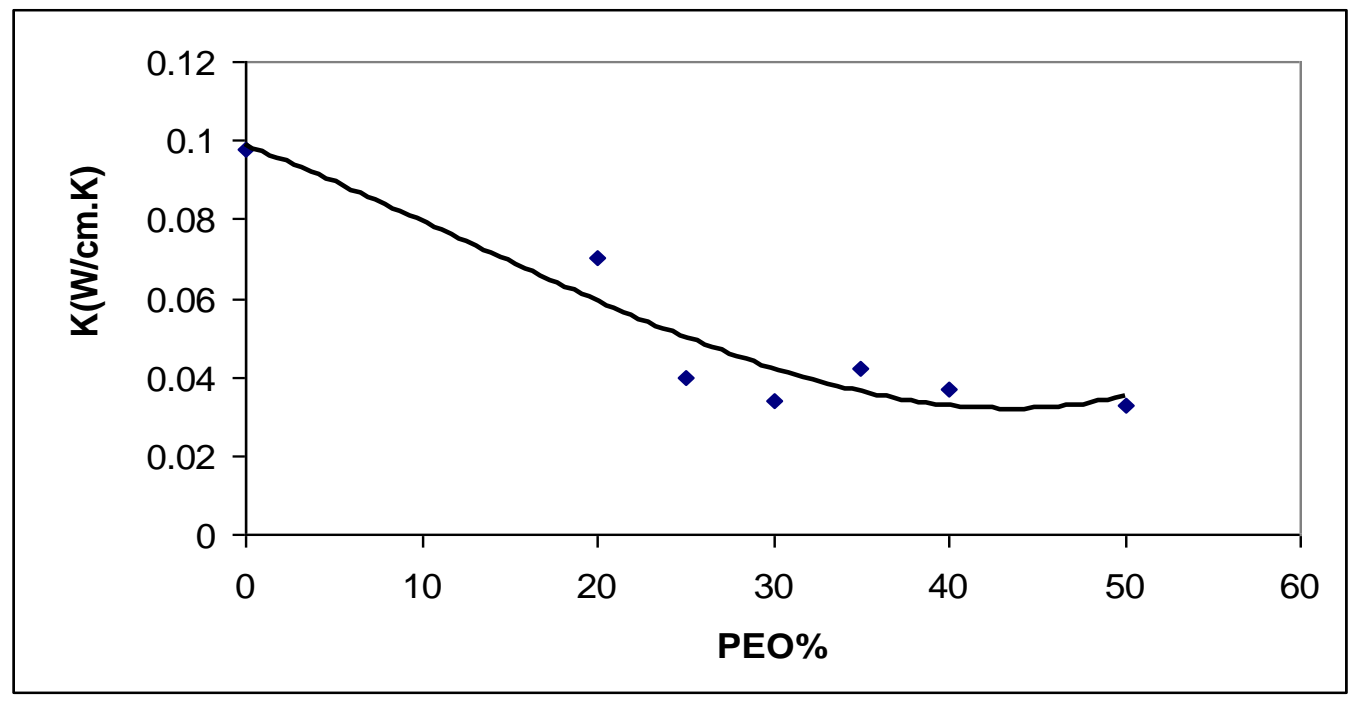

Figure 16-The PVA thermal conductivity changes with PEO loading.

\section{Conclusion:}

The results proved an increase in Tg with the increase in PEO ratio, whereas the melting point was fixed at about $\mathrm{Tm}=310^{\circ} \mathrm{C}$. TGA results showed that PEO addition caused overlapping between degradation stages and shifting in the second stage to higher degradation temperatures, that was due to the compatibility of PVA and PEO as well as the improved thermal stability of polymer blends. The mechanical properties of the samples involved were studied. The results showed that the tensile strength decreases with PEG addition .A ratio of 25\% PEO/PVA was selected according to( its ultimate strength $(26.67 \mathrm{MPa})$ ) to study the UV-exposure effects with various periods of time $(25,60$,and $90 \mathrm{Hr}$.) on the mechanical properties, It was found minor changes in ultimate strength were observed at up to $60 \mathrm{Hr}$ exposure time, then there was a little decrease in the ultmate strength at 90 $\mathrm{Hr}$ )exposure time .It was experimentally observed a value of thermal conductivity of PVA= $0.099 \mathrm{~W} / \mathrm{cm} . \mathrm{K}$. The results also proved a decrease in thermal conductivity with the increase of PEO loading.

\section{References}

1. Knop, K., Hoogenboom, R., Fischer, D.,Schubert. 2010. U.S. Poly(ethylene glycol) in Drug Delivery:Pros and Cons as Well as Potential Alternatives. Angew. Chem. Int. Ed.: 49:6288-6308.

2. Martens, P., Holland, T., Anseth, K.S. 2002. Synthesis and Characterization of Degradable Hydrogels Formed from Acrylate Modified Poly(vinyl alcohol) Macromers. Polymer, 43:60936100 .

3. Tubbs, R.K. 1966, Sequence Distribution of Partially Hydrolyzed Poly(vinyl acetate). J. Polym. Sci., 4: 623-629.

4. Tacx, J.C.J.F., Schoffeleers, H.M.; Brands, A.G.M.;Teuwen, L. 2000, Dissolution Behavior and Solution Properties of Polyvinylalcohol as Determined by Viscometry and Light Scattering in DMSO, Ethylene Glycol and Water. Polymer, 41: 947-957. 
5. Hassan, C.M., Peppas, N.A. 2000. Structure and Applications of Poly(vinyl alcohol) Hydrogels Produced by Conventional Crosslinking or by Freezing/Thawing Methods. Adv. Polym. Sci., 153:37-65.

6. Wan, L.S.C., Lim, L.Y. 1992. Drug Release from Heat Treated Polyvinyl Alcohol Films. Drug Dev.Ind. Pharm., 18:1895-1906.

7. P. Gölitz "Der Druck steigt". Angewandte Chemie. , 2006: 118: 5152-5154..

8. P. Gölitz, 1988,Editorial". Angewandte Chemie, 100: 3.

9. J. Jose, M. A. Al-Harthi, M. A.-A. AlMa'adeed, J. B. Dakua, and S. K. De, 2015 ,Effect of graphene loading on thermomechanical properties of poly(vinyl alcohol)/starch blend, Journal of Applied Polymer Science, 132(16).

10. Y. Li, W. Wu, F. Lin, and A. Xiang, 2012, The interaction between poly(vinyl alcohol) and lowmolar-mass poly(ethylene oxide), Journal of Applied Polymer Science, 126(1): 162-168.

11. O. A. Bin-Dahman, J. Jose, and M. A. Al-Harithi, 2015, Compatibility of poly(acrylic acid)/starch blends,"Starch - Stärke,, 67, ( 11-12):1061-1069

12. C. K. Chan and I. M. Chu, 2002, Biomaterials, 23(11): 2353-2358.

13. O. A. Bin-Dahman, J. Jose, and M. A. Al-Harithi, 2017, Starch - Stärke,: 69: 7-8

14. J. Jose, and M. A. Al-Harthi, , 2017, "Citric acid crosslinking of poly(vinyl alcohol)/starch/graphene nanocomposites for superior properties," Iranian Polymer Journal, 26 ( 8): $579-587$.

15. J. Jose, S. K. de, M. A. A. AlMa'adeed et al., 2015 ,Compatibilizing role of carbon nanotubes in poly(vinyl alcohol)/starch blend, Starch - Stärke,: 67, .(1-2), 147-153.

16. O. A. Bin-Dahman, F. Shehzad, and M. A. al-Harthi, "Influence of graphene on the nonisothermal crystallization kinetics of poly(vinyl alcohol)/starch composite," Journal of Polymer Research, 2018: 25( 1).

17. O. Bin-Dahman, M. Rahaman, D. Khastgir, and M. A. Al-Harithi, 2018 ,Electrical and dielectric properties of poly(vinyl alcohol)/starch/graphene nanocomposites, The Canadian Journal of Chemical Engineering,96(4): 903-9112018

18. G. Swift, 1994, "Water-soluble polymers," Polymer Degradation and Stability,45( 2): 215-231.

19. R. J. Sengwa, S. Choudhary, and S. Sankhla, 2010, Dielectric properties of montmorillonite clay filled poly(vinyl alcohol)/poly(ethylene oxide) blend nanocomposites," Composites Science and Technology, 70( 11):1621-1627.

20. K. Abdel Tawab, M. M. Magida, and S. M. Ibrahim, 2011, Effect of ionizing radiation on the morphological, thermal and mechanical properties of polyvinyl alcohol/polyethylene glycol blends," Journal of Polymers and the Environment,19( 2):440-446.

21. R. J. Sengwa and S. Choudhary, 2014, Structural characterization of hydrophilic polymer blends/montmorillonite clay nanocomposites," Journal of Applied Polymer Science,:131(16).

22. Jose, F. Shehzad, and M. A. Al-Harthi, 2014, Preparation method and physical, mechanical, thermal characterization of poly(vinyl alcohol)/poly(acrylic acid) blends,Polymer Bulletin ,71(11):2787-2802.

23. Bin-Dahman, J. Jose, and M. A. Al-Harithi, 2015 ,Compatibility of poly(acrylic acid)/starch blends,Starch - Stärke,67( 11-12):1061-1069.

24. P. A. Sreekumar, M. A. Al-Harthi, and S. K. De, 2012, Effect of glycerol on thermal and mechanical properties of polyvinyl alcohol/starch blends," Journal of Applied Polymer Science, 123( 1):135-142.

25. Elisabeta E.T,Mona E.P.,Maria R.,and Ovidiu P, 2015,Romanian ,Biotechnological letters,20(2).

26. Todd , C , 2002,Meeting The Therapeutic Challenge of The Patient With Osteoarthritis,J . AM .Pharm . Assoc . (Wash) , : 42:74-82.

27. Da Camara , C. C., Dowless, G . V ., 1998, Glucosamine Sulfate For Osteoarthritis, Ann . Pharmacother .32:580-587.

28. White , T . Stegemann , J . A ., 2001,Environmentally Perferred Materials In Advance in Environmenta Materials" Material Research Society, II : 249-260 .

29. Fahad H. Falqi, Osamah A. Bin-Dahman,M. Hussain, and Mamdouh A. Al-Harthil, 2018, Preparation of Miscible PVA/PEG Blends and Effect of Graphene Concentration on Thermal, Crystallization, Morphological, and Mechanical Properties of PVA/PEG (10 wt\%) Blend, International Journal of Polymer Science, ID 8527693: 10 
30. M. Abu Ghalia and Y. Dahman, 2015 ,Radiation crosslinking polymerization of poly (vinyl alcohol) and poly (ethylene glycol) with controlled drug release, Journal of Polymer Research, 22(11): 218.

31. V. D. Monopoli, L. R. Pizzio, and M. N. Blanco, 2008, Polyvinyl alcohol-polyethylenglycol blends with tungstophosphoric acid addition: Synthesis and characterization,Materials Chemistry and Physics,108( 2-3): 331-336.

32. M. Abu Ghalia and Y. Dahman, 2015 ,Radiation crosslinking polymerization of poly (vinyl alcohol) and poly (ethylene glycol) with controlled drug release, Journal of Polymer Research, , 22( 11): 218.

33. C. Wang, L. Feng, H. Yang et al., 2012, Graphene oxide stabilized polyethylene glycol for heat storage,Physical Chemistry Chemical Physics,14( 38):13233-13238.

34. Elisabeta E.T,Mona E.P.,Maria R.,and Ovidiu P,Romanian, 2015 ,Biotechnological letters,20(2).

35. Jobin Jose,Mamdouh A,Al-Harthi,Mariam Al-Ali AL-maadeed,Jolly Bhadra Dakua,and Sadhan K.Dey,Journal of applied polymer Science.2015.

36. P. A. Sreekumar, M. A. Al-Harthi, and S. K. De, 2012,Studies on compatibility of biodegradable starch/polyvinyl alcohol blends, Polymer Engineering and Science,52(10):2167-2172.

37. V. D. Monopoli, L. R. Pizzio, and M. N. Blanco, 2008, Polyvinyl alcohol-polyethylenglycol blends with tungstophosphoric acid addition: Synthesis and characterization,Materials Chemistry and Physics, 108( 2-3):, 331-336.

38. Ye B, Li Y, Chen Z, Wu Q-Y, Wang W-L, Wang T et al, 2017,Degradation of polyvinyl alcohol (PVA) by UV/chlorine oxidation: radical roles, influencing factors, and degradation pathway. Water Res, 124:381-387

39. Niu Y, Zhang X, He X, Zhao J, Zhang W, Lu C, 2015, Effective dispersion and crosslinking in PVA/cellulose fibre biocomposites via solid-state mechanochemistry. Int $\mathrm{J}$ Bio Macromol ,72:855-861.

40. Sonker AK, Wagner HD, Bajpai R, Tenne R, Sui X, 2016, Effects of tungsten disulphide nanotubes and glutaric acid on the thermal and mechanical properties of polyvinyl alcohol. Compos Sci Technol,127:47-53.

41. Awad SA, Khalaf EM , 2018,Evaluation of the photostabilizing efficiency of polyvinyl alcoholzinc chloride composites. J Thermoplast Compos Mater..

42. Sameer A. Awad, Eman M. Khalaf, 2019, Investigation of Photodegradation Preventing of Polyvinyl Alcohol/Nanoclay Composites, Journal of Polymers and the Environment,_September: 27, (9):1908-1917 .

43. Oraby, A.H.; Hezma, A.M.; Elashmawi, I.S.; Alluheebe, M.A. 2015, Verification of the changes in the structural and optical properties of PVA/PEO embedded by lithium chloride. Res. J. Pharm. Biol. Chem. Sci.: 6:724-734.

44. Meikhail, M.S.; Oraby, A.H.; Farea, M.O.; Abdelghany, A.M. 2014, Spectroscopic studies of PVA/PEO hydrogel filled with cesium chloride. Res. J. Pharm. Biol. Chem. Sci., 5, 976-983.

45. Ragab, H.M. 2017, Studies on the thermal and electrical properties of polyethylene oxide/polyvinyl alcohol blend by incorporating of cesium chloride. Results Phys.7: 2057-2065.

46. Lian, Z.; Ye, L. 2017,Structure and properties of PVA/PEO hydrogel prepared by freezing/thawing method. J. Thermoplast. Compos. Mater.:26: 912-922.

47. Joge, P.; Kanchan, D.K.; Sharma, P.; Gondaliya, N. 2013, Conductivity studies on filler free and filler doped PVA-PEO based blend polymer electrolytes. Adv. Mater. Res.:665: 227-232.

48. Margaritis, E.; Kang, J. 2017, Relationship between green space-related morphology and noise pollution. Ecol. Indic.72:921-933.

49. Huana Liu,and Baoqi Zuo, 2018,Structure and Sound Absorption Properties of Spiral Vane Electrospun PVA/PEO Nanofiber Membranes, Applied Sciences,: 8(2):296 . 